\title{
A Soil Inoculant Inhibits Armillaria mellea In Vitro and Improves Productivity of Grapevines with Root Disease
}

\author{
Kendra Baumgartner and Amy E. Warnock, United States Department of Agriculture-Agricultural Research Ser- \\ vice, Davis, CA 95616
}

\begin{abstract}
Baumgartner, K., and Warnock, A. E. 2006. A soil inoculant inhibits Armillaria mellea in vitro and improves productivity of grapevines with root disease. Plant Dis. 90:439-444.

A soil inoculant, Vesta (Biologically Integrated Organics, Inc., Sonoma, CA), was tested for its ability to inhibit Armillaria mellea, causal agent of Armillaria root disease of grapevine (Vitis vinifera). Colony diameter of $A$. mellea was significantly inhibited by undiluted inoculant $(P<$ 0.0001 ) and by bacterial isolates cultured from the inoculant (Bacillus subtilis, B. lentimorbus, Comamonas testosteroni, Pseudomonas aeruginosa, $P$. mendocina; $P<0.0001)$ relative to diameter of the nontreated control. Efficacy of the inoculant for postinfection control of Armillaria root disease of grapevine was examined in an A. mellea-infested vineyard in northern California. Inoculant was applied via drip-irrigation to vine rows in replicate blocks in 2003 and 2004. Yield, growth, mineral nutrition, and juice quality parameters of healthy and symptomatic vines were measured in treated and nontreated vine rows. Significantly decreased petiole P and K concentrations and significantly lower soluble solids content in fruit from symptomatic vines demonstrated that Armillaria root disease negatively affects vine mineral nutritional status and fruit quality, findings that have not been previously reported for an agronomic host of A. mellea. The inoculant significantly increased cluster weights of symptomatic vines (109.63 g/cluster), relative to those of symptomatic-nontreated vines ( $92.05 \mathrm{~g} / \mathrm{cluster}$ ), to levels comparable to those of healthy vines $(122.09 \mathrm{~g} /$ cluster). However, the inoculant did not decrease the rate of symptom development or mortality of treated vines from 2002 to 2004 . The results of our field experiment suggest that the inoculant may not prevent Armillaria root disease, but can provide therapeutic benefit by improving productivity of infected vines.
\end{abstract}

Additional keywords: biological control

Armillaria root disease of grapevine ( $\mathrm{Vi}$ tis vinifera L.) is caused by Armillaria mellea (Vahl:Fr.) P. Kumm., a fungal pathogen that also infects and decays the woody roots of many common forest trees in California, such as Quercus kellogii Newb. (California black oak) (5). Where forests are converted to vineyards, mycelium of A. mellea can survive in partially decayed tree roots and infect grapevines up to several years after planting (6).

Most research on the control of Armillaria root disease on cultivated plants has focused on preplant use of soil fumigants to kill inoculum of the pathogen in partially decayed tree roots $(1,8,20,21)$. Methyl bromide and carbon disulfide can kill mycelium in partially decayed tree roots, but not to the depths in soil necessary to reach all of the infested roots (8), especially on sites that were cleared of

Corresponding author: K. Baumgartner

E-mail: kbaumgartner@ucdavis.edu

Accepted for publication 1 November 2005.

DOI: 10.1094/PD-90-0439

This article is in the public domain and not copyrightable. It may be freely reprinted with customary crediting of the source. The American Phytopathological Society, 2006. mature forest trees. Soil fumigants typically provide control for several years (17). However, replants eventually become infected when their roots contact inoculum that escapes the effects of soil fumigation. In this way, reliance on soil fumigation for control of Armillaria root disease leads grape-growers into an endless cycle of removing dead vines, fumigating, and replanting. Nonetheless, soil fumigation is one of few available control treatments. Given that methyl bromide will eventually be banned from use in California vineyards, an alternative to soil fumigation is needed.

Another preplant treatment that has been examined is the use of antagonistic fungi for biological control of A. mellea mycelium in buried tree roots. This approach was pursued based on findings that fumigants either kill or weaken A. mellea mycelium in buried wood segments $(16,19$, 20,22 ), which predisposes the pathogen to attack by antagonistic soilborne fungi such as Trichoderma viride Pers.:Fr., a hypothesis that was first proposed by Bliss (8). Although some tested Trichoderma isolates show excellent in vitro and in vivo (25) inhibition of A. mellea growth, it is not clear that necessary concentrations of antagonistic fungi can be achieved in field soil (26).
Given the demonstrated futility of preplant soil fumigation and the difficulty involved with inoculating soils with sufficient populations of antagonistic fungi, efforts may be better spent on postinfection treatments that improve an infected grapevine's tolerance of Armillaria root disease. We might expect postinfection treatments to be a successful approach for two important reasons: (i) A. mellea is a slow-growing fungus (colony growth on $1 \%$ malt extract agar incubated at room temperature is approximately $5 \mathrm{~mm} /$ week), and (ii) grapevines are relatively tolerant of infection, based on the fact that it typically takes several years for an infected grapevine to die from Armillaria root disease (6). In addition, a recent study demonstrated the efficacy of root collar excavation for postinfection treatment of grapevines infected with A. mellea (4). The practice significantly mitigates one of the disease symptoms, decreased fruit production (4), by causing mycelial fans to recede from the root collar, thereby improving the function of vascular tissue at the base of the trunk. Therefore, control measures designed to enhance the yield of infected grapevines may prove to be more costeffective than replanting, given that replants are not immediately productive and may eventually become infected by $A$. mellea.

The objective of this research was to examine the efficacy of a commercially available soil inoculant, Vesta (Biologically Integrated Organics, Inc., Sonoma, CA), for postinfection control of Armillaria root disease of grapevine. The inoculant is produced by a proprietary compost fermentation process, the product of which contains viable populations of bacteria that may serve as antagonists of A. mellea. Microbial inoculants and other biologically based products are of interest to grapegrowers who want to reduce their reliance on pesticides.

A series of laboratory experiments was used to examine inhibition of A. mellea by the inoculant, and to isolate and identify bacteria associated with inhibition. A field experiment was conducted in an $A$. mellea-infested vineyard to determine if applications of the inoculant to symptomatic vines could improve the following performance parameters: yield, growth, mineral nutrition, and juice quality. Given that yield and growth of symptomatic vines are known to be significantly lower 
than those of healthy vines (4), we viewed amelioration of these impacts as measures of the efficacy of the inoculant. Examining naturally infected vines in the field is preferable to inoculating potted vines with $A$. mellea in the greenhouse, in that the latter is neither a reliable nor timely means of obtaining infected vines $(23,24,27)$. The factorial design of the field experiment necessitated the inclusion of healthy vines, allowing for quantification of effects of the disease on vine mineral nutrition and juice quality, a logical complement to existing knowledge of the negative effects of the disease on vine yield and growth.

\section{MATERIALS AND METHODS}

Inhibition assays. The inoculant, Vesta (Biologically Integrated Organics, Inc., Sonoma, CA), is produced by fermentation of a proprietary blend of composted materials, the product of which contains viable populations of bacteria that are monitored throughout the production process using colony counts of functional groups of microorganisms (heterotrophic bacteria, anaerobic bacteria, Pseudomonads, nitrogenfixing bacteria). After fermentation, the resulting product is amended with humic acid and other organic acids. Vesta is a brown, opaque liquid that is applied to vine rows by injection into the dripirrigation system, with agitation, but can also be applied to individual vines as a soil drench. Recommended application rates are 75 to 112 liters/ha (8 to 12 gallons/acre) per season.

The soil inoculant was used to challenge A. mellea in inhibition assays. Assays were conducted on yeast extract malt agar (YMA) on 100-mm-diameter petri plates with an A. mellea isolate cultured from symptomatic vines in the experimental vineyard. A sterile, 6-mm-diameter paper disk was saturated with $20 \mu \mathrm{l}$ of undiluted inoculant and placed $5 \mathrm{~mm}$ from an $A$. mellea agar plug on each of four YMA plates. Disks saturated with sterile water served as nontreated controls. Diameters of A. mellea colonies were recorded after incubation at $25^{\circ} \mathrm{C}$ for 21 days. Inhibition assays were repeated three times, to give a total of 12 plates for the inoculant and 12 plates for the nontreated control (water). Bacteria were isolated from expanding colonies surrounding the inoculant disks from plates on which A. mellea growth was inhibited the most. These isolates were used in the remaining laboratory tests.

Bacterial isolates cultured from the inoculant were used to challenge A. mellea in a second set of inhibition assays. Assays were conducted as described above with four plates per bacterial isolate. A sterile paper disk saturated with $20 \mu \mathrm{l}$ of a turbid suspension of vegetative cells (approximately $10^{8}$ cells $/ \mathrm{ml}$ collected from a $24-\mathrm{h}$ old culture on YMA) in sterile water of each bacterial isolate was placed $5 \mathrm{~mm}$ from each A. mellea plug. Sterile disks with sterile water served as nontreated controls. Diameters of A. mellea colonies were evaluated as described above. Inhibition assays were repeated twice, to give a total of eight plates for each bacterial isolate and eight plates for the nontreated control (water). Bacterial isolates that limited A. mellea colonies to the same diameter as did the inoculant were identified by fatty acid methyl ester (FAME) analysis. Fatty acids were extracted and analyzed by gas chromatographic analysis (BBC Laboratories, Tempe, $\mathrm{AZ}$ ) using the technique described by Kloepper et al. (18). Identifications were based on similarity index values of each isolate, which represent the similarity between the FAME profile of the unknown isolate and a bacterial species from a database of FAME profiles of known isolates, on a scale of 0.001 (least similar) to 0.999 (most similar).

Field trials. A field experiment was conducted in a commercial vineyard in Napa County, CA, during the 2003 and 2004 growing seasons. A. mellea had been discovered in 2000 on dead and dying vines in the vineyard. The vineyard was planted in 1997 with dormant bench grafts of $V$. vinifera cv. Cabernet Sauvignon (clone 337) on 110R rootstock (V. berlandieri Planch. $\times V$. rupestris Scheele). The 3.4-ha site was previously an oak woodland. Vine spacing was $1.8 \mathrm{~m}$ within rows and $2.3 \mathrm{~m}$ between rows, with eastwest row orientation. Vines were trained as unilateral cordons to a vertical shoot positioning trellis system. The vineyard was drip-irrigated (43 kl/ha/week, May-July; $85 \mathrm{kl} / \mathrm{ha}$ /week, July-October) with one drip emitter per vine positioned $0.3 \mathrm{~m}$ from each vine trunk.

In July 2002, the status of every vine was categorized, based on approximate shoot length, as symptomless ( $\geq 1 \mathrm{~m})$, moderately symptomatic $(0.3$ to $1 \mathrm{~m})$, or severely symptomatic $(\leq 0.3 \mathrm{~m})$, using the procedure described previously (4). Severely symptomatic vines were excluded from this study because they often die before the fruit can mature (4). Vine status was documented at harvest on the following dates: 19 September 2002, 18 October 2003, and 23 September 2004. In November 2002, the presence of A. mellea infection on moderately symptomatic vines was verified by clearing soil away from the root collars to a depth of approximately 0.3 $\mathrm{m}$ and removing a small piece of bark, ca. $2 \mathrm{~cm}^{2}$ area, from the base of the trunk and from each main root to expose mycelial fans. The same method was used to verify absence of A. mellea on symptomless vines. Hereafter, symptomless vines with no mycelial fans at their root collars will be referred to as "healthy", with the understanding that some might actually have been infected, but were not yet symptomatic. Moderately symptomatic vines with mycelial fans at their root collars will be referred to as "symptomatic".
The vineyard included three replicate blocks $(0.44 \mathrm{ha} / \mathrm{block})$, with a nontreated buffer row between blocks. Experimental treatments were arranged in a split plot design with inoculant treatment (treated or nontreated) as the main plot and vine status (healthy or symptomatic) as the subplot. An experimental block consisted of 10 vineyard rows: four adjacent treated rows plus five adjacent nontreated rows, separated by a nontreated buffer row. Healthy and symptomatic vines, the subplot treatments, were randomly selected from within the treated and nontreated rows, the main plot treatments, which were randomly assigned to a half of each block. Healthy vines were included for comparison with symptomatic vines, in order to verify the negative effects of Armillaria root disease on the symptomatic vines, evidence without which inoculant effects may be considered somewhat specious. In 2003 and 2004, the inoculant was injected into the irrigation system of treated rows at the following rates: budbreak (46.77 liters/ha), full bloom (46.77 liters/ha), 15\% veraison (onset of fruit ripening) (18.71 liters/ha), and $85 \%$ veraison (18.71 liters/ha). All three phenological stages are visible in the field and are, therefore, typically used by grape-growers to schedule fungicide and fertilizer applications. Nontreated rows received equal rates of irrigation water. In treated and nontreated sections of each block, 12 healthy and 12 symptomatic data vines were randomly chosen for measurement of yield, growth, mineral nutrition, and juice quality parameters, for a total of four experimental treatments.

Fruit clusters from sampled vines were counted, harvested, and weighed on 18 October 2003 and 23 September 2004, resulting in a total of three yield parameters for each vine: cluster number, yield (kg/vine), and average cluster weight (yield [g]/cluster number). At harvest, one cluster/vine from five vines per treatment per block were subsampled and analyzed for three juice quality parameters: total soluble solids ( ${ }^{\circ}$ Brix), measured with a table-top refractometer (Carl Zeiss Inc., Thornwood, NY); pH (Accumet pH meter, Fisher Scientific, Fair Lawn, NJ); and titratable acidity ( $\mathrm{g}$ tartaric acid/liter of juice; [TA]), using standard methods (9). TA was estimated based on the volume of $0.1 \mathrm{~N} \mathrm{NaOH}$ required to bring about a color change in a mixture of $5 \mathrm{ml}$ juice from each five-cluster sample, $100 \mathrm{ml}$ distilled water, and 2 drops phenolphthalein (indicator). Total soluble solids, $\mathrm{pH}$, and TA are routinely measured by grapegrowers and winemakers for the purpose of timing harvest because all three parameters affect wine quality. From the same vines from which yields were measured, dormant canes were pruned and weighed on 21 January 2004 and 14 December 2004. Average shoot weight was obtained 
by dividing pruning weight by shoot number, resulting in a total of three growth parameters: shoot number, pruning weight ( $\mathrm{kg} / \mathrm{vine})$, and shoot weight ( $\mathrm{g}$ ).

Petioles for analyses of vine mineral nutritional composition were collected at full bloom (24 June 2003, 4 June 2004). Within each treatment per block, 20 petioles were collected from each data vine using a standard petiole sampling procedure (30), pooled, oven-dried $\left(60^{\circ} \mathrm{C}, 7\right.$ days), and pulverized. Subsamples were analyzed for total nitrogen $(\mathrm{N})$, total phosphorus (P), and potassium (K) (DANR Laboratories, University of California, Davis). Soil samples were collected adjacent to the same vines from which petioles were collected, using a hand auger to a depth of $15 \mathrm{~cm}$ at a distance of approximately $0.2 \mathrm{~m}$ from the base of the vine. Soil samples were pooled within each treatment per block, oven dried $\left(60^{\circ} \mathrm{C}, 7\right.$ days), pulverized, and analyzed for total $\mathrm{N}$, nitrate-nitrogen $\left(\mathrm{NO}_{3}-\mathrm{N}\right)$, Olsen $\mathrm{P}$, exchangeable $\mathrm{K}$, total carbon $(\mathrm{C}), \mathrm{pH}$, and cation exchange capacity.

Statistical analyses. Analyses of variance (ANOVA) were used to determine the effects of the inoculant and of 12 antagonistic bacteria isolated from the inoculant on A. mellea growth, using the MIXED procedure in SAS (SAS System, version 8.2; SAS Institute Inc., Cary, NC) with Kenward-Roger as the denominator degrees of freedom method. Replications of these experiments were considered fixed effects. ANOVAs also were used to determine the effects of vine status (healthy or symptomatic), inoculant (treated or nontreated), year (2003 or 2004), and their interactions on yield, growth, nutrition, and juice quality parameters. Block and block interactions were considered random effects. Tukey's tests were used for treatment mean comparisons. A square root transformation was applied to pruning weights and shoot weights to homogenize variances; reversetransformed treatment means and 95\% confidence intervals are presented in the text. Chi-square tests of independence were used to determine the relation between treatment with the inoculant and counts of vines that changed health status from 2002 to 2003 , and from 2003 to 2004.

\section{RESULTS}

Inhibition assays. In the presence of the inoculant, A. mellea colonies grew to diameters of 5 to $12 \mathrm{~mm}$ (including the 4mm-diameter agar plug) on all 12 plates, compared to 18 to $22 \mathrm{~mm}$ on control plates. This differential reflected a significant inhibitory effect of the inoculant on the pathogen $(P<0.0001)$. Twelve bacteria, isolated from plates on which $A$. mellea colonies were limited to $<8 \mathrm{~mm}$, were used in a second set of inhibition assays. Seven of these isolates limited expansion of A. mellea colonies to 5 to 8 $\mathrm{mm}$. When compared to the control plates, where A. mellea colonies ranged from 18 to $22 \mathrm{~mm}$, inhibition of the pathogen by the seven isolates was significant $(P<$ $0.0001)$. Five species were identified from the seven isolates that inhibited A. mellea in vitro to the same extent as the inoculant. These were (with FAME similarity index values following in parentheses) two isolates of Bacillus subtilis (Ehrenberg 1835) Cohn 1872 (0.741 and 0.728), two isolates of B. lentimorbus Dutky 1940 (0.707 and 0.671), one isolate of Comamonas testosteroni (Marcus and Talalay 1956) Tamaoka et al. 1987 (0.944), one isolate of Pseudomonas aeruginosa (Schroeter 1872) $\mathrm{Mi}$ gula 1900 (0.932), and one isolate of $P$. mendocina Palleroni 1970 (0.661).

Field trials. In both years, the inoculant had significant effects on yields and cluster weights of symptomatic vines, as detected by ANOVA, but no effects on healthy vines; hence, the significant status $\times$ treatment interaction effects on yield and cluster weight (Table 1). Although there was a significant effect of the status $\times$ treatment interaction on yield, means comparisons with Tukey's tests following ANOVA showed no significant differences between yields of symptomatic-treated and symptomatic-nontreated vines (Fig. 1A). In contrast, cluster weights of symptomatic vines treated with the inoculant were $17.58 \mathrm{~g}$ more than those of symptomaticnontreated vines, and these differences were significant (Fig. 1B). In fact, cluster weights of symptomatic-treated vines were as high as those of healthy vines.

Among the three factors examined by ANOVA (year, vine status, inoculant treatment), inoculant treatment was the only factor that significantly affected soil

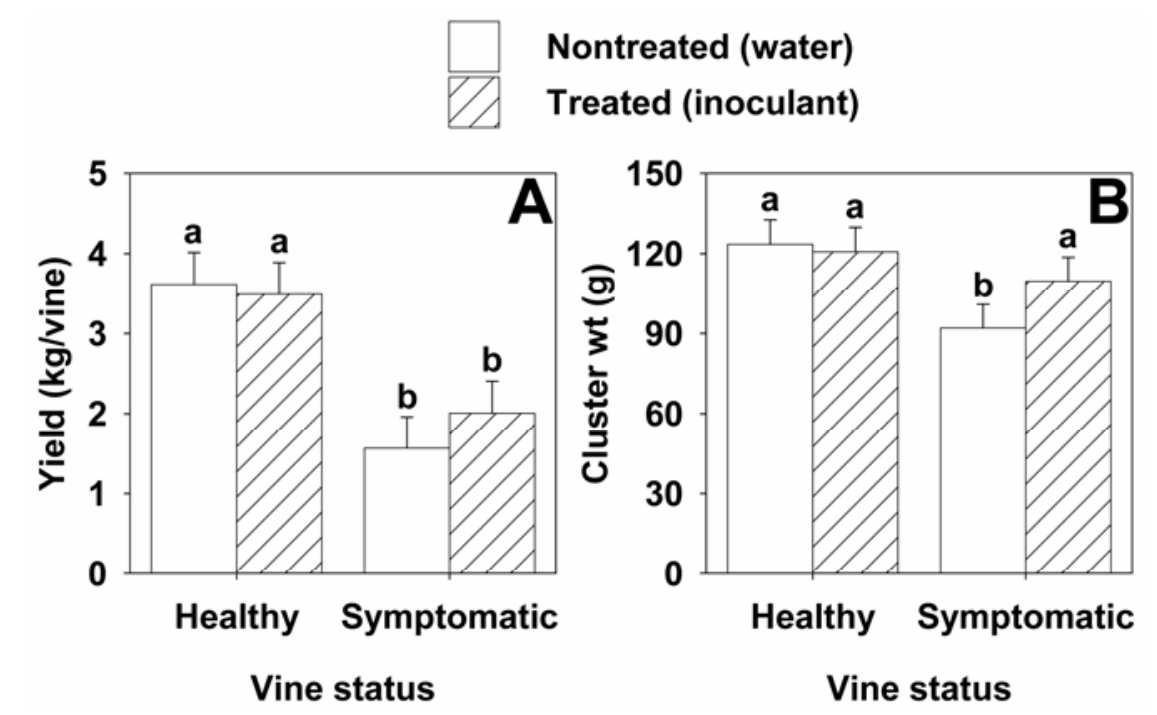

Fig. 1. Effects of the inoculant on $\mathbf{A}$, yield, and $\mathbf{B}$, cluster weight of healthy and symptomatic grapevines in a vineyard infested with Armillaria mellea. Error bars represent $95 \%$ confidence limits. Each column is the mean of 78 observations summed over 2003 and 2004 harvests. Columns with different letters are significantly different at $P \leq 0.05$, Tukey's test.

Table 1. Analyses of variance for combined 2003 and 2004 cluster number, yield, and cluster weight of healthy and symptomatic grapevines, with or without inoculant treatment, in a vineyard infested with Armillaria mellea

\begin{tabular}{|c|c|c|c|c|c|c|}
\hline \multirow[b]{2}{*}{ Source ${ }^{y}$} & \multicolumn{2}{|c|}{ Cluster number } & \multicolumn{2}{|c|}{ Yield } & \multicolumn{2}{|c|}{ Cluster weight } \\
\hline & Den df ${ }^{z}$ & $F$ value & Den $\mathbf{d f}^{z}$ & $F$ value & Den df $\mathbf{f}^{\mathbf{z}}$ & $F$ value \\
\hline Year & 2 & 3.69 & 2 & 3.98 & 239 & 3.72 \\
\hline Status & 236 & $165.11 * * *$ & 237 & $150.79 * * *$ & 239 & $29.58^{* * *}$ \\
\hline Year $\times$ status & 236 & $7.21 * *$ & 237 & $6.13 *$ & 239 & 0.61 \\
\hline Treatment & 2 & 0.61 & 2 & 0.78 & 4 & 2.81 \\
\hline Year $\times$ treatment & 237 & 0.01 & 237 & 0.52 & 239 & $3.95^{*}$ \\
\hline Status $\times$ treatment & 237 & 0.46 & 237 & $3.88^{*}$ & 239 & $6.81 * *$ \\
\hline Year $\times$ status $\times$ treatment & 237 & 0.87 & 237 & 0.83 & 239 & 0.53 \\
\hline
\end{tabular}

${ }^{y}$ Source of variation: 2003 or 2004 (year), healthy or symptomatic (status), nontreated or treated (inoculant treatment).

${ }^{\mathrm{z}}$ Denominator degrees of freedom. Numerator degrees of freedom are 1 for all main and interaction effects; *, **, and *** indicate significance at $P \leq 0.05$, 0.01 , and 0.0001 , respectively. 
composition, specifically soil $\mathrm{C}(P=$ $0.0351)$. Soil from treated vines had significantly higher soil $\mathrm{C}$ than that of nontreated vines (34.45 and $28.80 \mathrm{mg} / \mathrm{g}$ dry soil of total $\mathrm{C}$, respectively). There were no significant differences in vine growth, petiole nutritional status, or juice quality between treated and nontreated vines (data not shown). In comparisons of counts of healthy, symptomatic, and dead vines between nontreated and treated rows (Table 2), chi-square analyses indicated that there were no significant differences in the proportions of healthy vines that developed symptoms or died from 2002 to 2003 or from 2003 to 2004 (Table 2). Similarly, the inoculant had no effect on the proportion of symptomatic vines that died in 2003 or 2004.

Symptomatic vines had significantly fewer clusters, lower yields, and lower cluster weights than healthy vines in both study years (Table 1), despite a significant decrease among healthy vines in cluster number per vine $(26.52$ versus $31.73 ; P=$ $0.0125)$ and yield per vine (3.23 versus $3.88 ; P=0.0111$ ) in 2004 , compared to 2003. Unlike healthy vines, symptomatic vines did not differ in cluster number or yield from 2003 to $2004(P=0.9997$ and $P$ $=0.9912$, respectively); hence the significant year $\times$ status interaction effects on cluster number and yield (Table 1). Compared to healthy vines, symptomatic vines had far fewer clusters, resulting in much lower yields in both years (17.01 clusters/vine and $1.79 \mathrm{~kg} / \mathrm{vine}$, averaged across 2003 and 2004, respectively).

Among the three factors examined in ANOVA (year, vine status, inoculant treatment), vine status was the only factor that significantly affected juice quality, vine growth, and petiole nutrition (Table 3). In addition to having fewer clusters, lower yields, and lower cluster weights, symptomatic vines produced clusters with significantly lower, by $1.38^{\circ} \mathrm{Brix}$, concentrations of total soluble solids than healthy vines in both years $(P=0.0170)$. Symptomatic vines had significantly fewer shoots $(P<0.0001)$, lower pruning weights $(P<$ $0.0001)$, and lower shoot weights $(P<$ $0.0001)$ than healthy vines. In fact, pruning weights of symptomatic vines were $58 \%$ lower than those of healthy vines. Symptomatic vines also had significantly lower petiole concentrations of $\mathrm{P}$ and $\mathrm{K}$ than healthy vines $(P=0.0021$ and $P=0.0108$,

Table 2. Effects of inoculant on status of healthy and Armillaria-affected vines, based on chi-square tests $^{\mathrm{w}}$ of independence between inoculant treatment and changes in health status

\begin{tabular}{|c|c|c|c|c|c|}
\hline \multirow{2}{*}{$\begin{array}{l}\text { Change in } \\
\text { health status }\end{array}$} & \multirow[b]{2}{*}{ Years } & \multicolumn{2}{|c|}{$\begin{array}{l}\text { Percentage of vines that } \\
\text { changed health status }\end{array}$} & \multirow[b]{2}{*}{$\chi^{2}$} & \multirow[b]{2}{*}{$P^{\mathrm{x}}$} \\
\hline & & Nontreated & Treated & & \\
\hline \multirow{2}{*}{ Healthy to dead } & 2002 to $2003^{y}$ & 0.45 & 0.57 & 0.111 & 0.74 \\
\hline & 2003 to $2004^{z}$ & 1.39 & 2.07 & 1.069 & 0.30 \\
\hline \multirow[t]{2}{*}{ Healthy to symptomatic } & 2002 to 2003 & 1.47 & 2.57 & 2.475 & 0.12 \\
\hline & 2003 to 2004 & 9.94 & 9.91 & 0.000 & 0.98 \\
\hline \multirow{2}{*}{ Symptomatic to dead } & 2002 to 2003 & 12.00 & 8.60 & 0.630 & 0.43 \\
\hline & 2003 to 2004 & 3.19 & 3.45 & 0.009 & 0.92 \\
\hline
\end{tabular}

${ }^{\mathrm{w}}$ Chi-square tests are based on comparisons between the number of vines in each category, summed across three replicate blocks of the experiment, in inoculant-treated and nontreated rows. $\mathrm{H}_{0}$ : there is no relation between treatment with the inoculant and change in health status; degrees of freedom $=1$.

${ }^{x}$ Probability that the differences between nontreated and treated rows in observed counts of vines that changed status are due to chance alone; differences are significant at $P \leq 0.05$.

${ }^{\mathrm{y}}$ Vine status was assessed on 19 September 2002, 18 October 2003.

z Vine status was assessed on 18 October 2003, 23 September 2004.

Table 3. Effects of Armillaria root disease on combined 2003 and 2004 growth, nutrition, and juice quality parameters of symptomatic vines, relative to those of healthy vines, in a vineyard infested with Armillaria mellea

\begin{tabular}{lrc}
\hline & \multicolumn{2}{c}{ Vine status $^{\mathbf{z}}$} \\
\cline { 2 - 3 } Parameters & Healthy & Symptomatic $^{-}$ \\
\hline Juice quality & & \\
$\quad$ Titratable acidity (g tartaric acid/liter) & $6.81 \mathrm{a}$ & $6.34 \mathrm{a}$ \\
Total soluble solids ( ${ }^{\circ}$ Brix) & $26.19 \mathrm{a}$ & $24.81 \mathrm{~b}$ \\
pH & $3.39 \mathrm{a}$ & $3.46 \mathrm{a}$ \\
Growth & & \\
Shoot number & $22.04 \mathrm{a}$ & $19.66 \mathrm{~b}$ \\
Pruning wt. (kg/vine) & $0.60 \mathrm{a}$ & $0.25 \mathrm{~b}$ \\
Shoot wt. (g) & $27.77 \mathrm{a}$ & $12.93 \mathrm{~b}$ \\
Petiole nutrition & & \\
Total N (mg/g dry tissue) & $9.32 \mathrm{a}$ & $10.07 \mathrm{a}$ \\
Total P (mg/g dry tissue) & $2.73 \mathrm{a}$ & $2.18 \mathrm{~b}$ \\
K (mg/g dry tissue) & $30.05 \mathrm{a}$ & $26.51 \mathrm{~b}$ \\
\hline
\end{tabular}

${ }^{\mathrm{z}}$ Sample sizes, summed over the growing seasons of 2003 and 2004, for means within each set of parameters are as follows: juice quality, $n=12$; growth, $n=144$; petiole nutrition, $n=12$. Means in the same row with different letters are significantly different at $P \leq 0.05$, Tukey's test. respectively). There were no significant differences in soil nutrition between healthy and symptomatic vines (data not shown). Averaged across healthy and symptomatic vines, the soil contained 1.95 $\mathrm{mg} / \mathrm{g}$ dry soil of total $\mathrm{N}, 49.68 \mu \mathrm{g} / \mathrm{g}$ dry soil of $\mathrm{NO}_{3}-\mathrm{N}, 51.00 \mu \mathrm{g} / \mathrm{g}$ dry soil of Olsen $\mathrm{P}$, and $430.89 \mu \mathrm{g} / \mathrm{g}$ dry soil of exchangeable K, with $\mathrm{pH} 6.2$, and $241.72 \mu \mathrm{mol} / \mathrm{g}$ dry soil of cation exchange capacity.

\section{DISCUSSION}

Using inhibition assays in the lab and repeated measurements of vine yield, growth, mineral nutrition, and juice quality in the field, we examined the potential of a microbial soil inoculant for postinfection management of Armillaria root disease of grapevine. The inoculant inhibited $A$. mellea, based on measures of colony diameter in culture. Our findings that symptomatic vines treated with inoculant had significantly higher cluster weights in both years and in all three replicate blocks of the vineyard indicate that applications of the inoculant may mitigate some of the effects of Armillaria root disease. Furthermore, there was no stimulatory effect of the inoculant on performance parameters of healthy vines, suggesting that the efficacy of the inoculant in improving cluster weights of symptomatic vines is associated with its effects on the pathogen.

Given that bacteria isolated from the inoculant (B. lentimorbus, B. subtilis, $C$. testosteroni, $P$. aeruginosa, $P$. mendocina) were individually found to inhibit $A$. mellea to the same extent as did the inoculant, it is possible these species are involved with inhibition. Reports that some of the bacteria we identified are antagonists of other pathogens, specifically $B$. subtilis $(7,28), P$. aeruginosa $(2,3,14)$, and $P$. mendocina (12), suggest that these species may inhibit $A$. mellea in infected vine roots. For example, B. subtilis has been shown to inhibit Phytophthora cactorum (Leb. \& Cohn) Schroeter (1886) in vitro and to reduce root rot incidence among infected apple seedlings (28). Dumas (15) and Delong et al. (13) demonstrated that Bacillus spp. and fluorescent pseudomonads isolated from forest soils inhibit the conifer pathogen A. ostoyae (Romagn.) Herink in vitro, suggesting that indigenous populations of antagonists may have a natural role in regulating Armillaria root disease in conifer forests. Even though we examined a different Armillaria species on a different host, results of research on antagonists of A. ostoyae have relevance to $A$. mellea inhibition by bacteria in the inoculant, given that A. mellea and A. ostoyae share a similar biology and infection cycle (29).

Bacteria isolated from the inoculant inhibited growth of A. mellea in vitro, and the inoculant compensated for compromised productivity of symptomatic vines in the field, results that infer direct or indi- 
rect effects of the bacteria on A. mellea. However, the inoculant did not decrease rates of symptom development or mortality. Without knowing the mechanism(s) by which bacteria in the inoculant inhibit $A$. mellea, it is difficult to explain these somewhat contradictory findings. One possible explanation is that the bacteria replace $A$. mellea in infected roots, a situation that Bliss (8) found with $T$. viride on Citrus root segments infected with $A$. mellea, demonstrating that the pathogen may not be capable of indefinitely defending infected roots from soil microbes. Replacement of $A$. mellea in infected roots by the bacteria in the inoculant would have no effect on vascular tissue already destroyed by $A$. mellea, but it would reduce the pathogen's food base and, thus, inhibit the colonization rate of adjacent root tissue. By inhibiting the spread of existing $A$. mellea infections, the bacteria in the inoculant may afford some level of root function recovery in symptomatic vines, thereby increasing cluster weights. Whatever the mechanism(s) of inhibition, the effects of the inoculant seem to be insufficient to prevent the onset of symptoms or eventual death of an infected vine.

While cluster weight increases were detected among symptomatic-treated vines in all three replicate blocks of the vineyard in both study years, our experiment included only one vineyard. Nonetheless, differences in yield and growth between healthy and symptomatic vines that we observed are similar to those reported for two other A. mellea-infested Napa vineyards (4). Given that the progression of Armillaria root disease in the examined vineyard does not appear to be unique in comparison with that of other northern California vineyards where similar measurements were made, our results should be applicable to other vineyards.

Our findings of significantly increased soil $\mathrm{C}$ among treated vines, including both healthy vines and symptomatic vines, in both study years, and in all replicate blocks of the vineyard, are puzzling. The inoculant clearly contains bacteria that, after application to the soil, may establish populations in the grapevine rhizosphere and contribute to soil C. However, it seems unlikely that the bacteria could bring about such a considerable change in soil $\mathrm{C}, 5.7$ $\mathrm{mg} / \mathrm{g}$ dry soil of total $\mathrm{C}$, in such a brief time. Research on sustainable cropping systems in northern California, in which one of the main objectives was to increase soil C, showed 10-fold lower increases in soil $\mathrm{C}$ than we observed in our study, and this was after 4 years of adding large quantities of compost and manure to the soil (11). If it was possible to raise soil $\mathrm{C}$ only by $0.5 \mathrm{mg} / \mathrm{g}$ dry soil of total $\mathrm{C}$ with 4 years of compost and manure amendments (11), it is surprising that we detected an increase in soil $\mathrm{C}$ of $5.7 \mathrm{mg} / \mathrm{g}$ dry soil of total $\mathrm{C}$ among treated vines in our experiment with 2 years of inoculant applications. Future investigations of the $\mathrm{C}$ sources and their concentrations in the inoculant might clarify this issue.

Although Armillaria root disease is known to decrease yield and growth of grapevines (4), negative effects of the disease on vine mineral nutrition and juice quality as documented in this study have not previously been reported. Aboveground symptoms of the disease result from destruction of vascular tissue at the root collar and on primary roots by $A$. mellea mycelium (6). Thus, an infected vine is unable to absorb an adequate supply of mineral nutrients. The lower yield and growth, reduced tissue $\mathrm{P}$ and $\mathrm{K}$, and lower soluble solids in fruit from symptomatic vines measured in this study are consistent with this expectation. Destruction of vascular tissue in the woody roots and associated poor nutrient uptake reduce a symptomatic vine's capacity; it has smaller shoots, and the buds on the shoots are less fruitful. In turn, deficiencies in $\mathrm{P}$ and $\mathrm{K}$ reduce photosynthetic capability, limiting yield and ripening. Growers could remedy this by reducing the crop load on symptomatic vines, in order to ensure proper ripening. While the petiole $\mathrm{P}$ and $\mathrm{K}$ concentrations that we measured among symptomatic vines were not technically deficient (adequate petiole concentrations at bloom are $>1.5 \mathrm{mg} \mathrm{P} / \mathrm{g}$ dry tissue and $>15 \mathrm{mg} \mathrm{K} / \mathrm{g}$ dry tissue; 10), they were statistically lower than those of healthy vines in all replicate blocks of the vineyard and in both study years. Therefore, it may be useful to evaluate foliar applications of $\mathrm{P}$ and $\mathrm{K}$ fertilizers to determine if they can compensate for lower root absorption of these macronutrients and, thus, help symptomatic vines tolerate Armillaria root disease.

The fact that significant cluster weight increases were measured among symptomatic-treated vines only 5 months after the first application are a clear indication of the inoculant's therapeutic benefit. Focusing control efforts on improving the productivity of infected vines that still produce normal clusters is more cost-effective than replanting, which requires the expense of new plant material, the labor costs for planting, and the lack of profit while waiting at least 2 years for replants to bear fruit. Inoculant applications require only a standard drip irrigation system already found in most California vineyards. The grower incurs a relatively small cost for purchase of the inoculant. The high value of Napa County grapes, $\$ 4,400 / 1,000 \mathrm{~kg}$ at the vineyard we examined, means that yield increases on symptomatic vines may offset the cost of the inoculant.

\section{ACKNOWLEDGMENTS}

We thank Jan Krupp for the use of his vineyard; J. Warren, B. Craughwell, and X. Cheng for field assistance; and C. Bull (United States Department of Agriculture-Agricultural Research Service
[USDA-ARS], Salinas, CA), K. Lewis (University of Northern British Columbia), M. Davis (University of California, Davis), and T. Gordon (University of California, Davis) for comments on this manuscript.

\section{LITERATURE CITED}

1. Adaskaveg, J. E., Forster, H., Wade, L., Thompson, D. F., and Connell, J. H. 1999. Efficacy of sodium tetrathiocarbonate and propiconazole in managing Armillaria root rot of almond on peach rootstock. Plant Dis. 83:240246.

2. Anjaiah, V., Koedam, N., Nowak-Thompson, B., Loper, J., Hofte, M., Tambong, J. T., and Cornelis, P. 1998. Involvement of phenazines and anthranilate in the antagonism of Pseudomonas aeruginosa PNA1 and Tn5 derivatives toward Fusarium spp. and Pythium spp. Mol. Plant-Microbe Interact. 11:847-854.

3. Audenaert, K., Pattery, T., Cornelis, P., and Hofte, M. 2001. Induced resistance to Botrytis cinerea by Pseudomonas aeruginosa: Role of siderophores and pyocyanin. IOBC/WPRS Bull. 24:37-41.

4. Baumgartner, K. 2004. Root collar excavation for postinfection control of Armillaria root disease of grapevine. Plant Dis. 88:1235-1240.

5. Baumgartner, K., and Rizzo, D. M. 2001 Ecology of Armillaria spp. in mixed-hardwood forests of California. Plant Dis. 85:947-951.

6. Baumgartner, K., and Rizzo, D. M. 2002. Spread of Armillaria Root Disease in a California vineyard. Am. J. Enol. Vitic. 53:197203.

7. Berger, F., Li, H., White, D., Frazer, R., and Leifert, C. 1996. Effect of pathogen inoculum, antagonistic density, and plant species on biological control of Phytophthora and Pythium damping-off by Bacillus subtilis Cot1 in highhumidity fogging glasshouses. Phytopathology 86:428-433.

8. Bliss, D. E. 1951. The destruction of Armillaria mellea in citrus soils. Phytopathology 41:665-683.

9. Boulton, R. B., Singleton, V. L., Bisson, L. F., and Kunkee, R. E. 1998. Principles and Practices of Winemaking. Aspen Publishers, Gaithersburg, MD.

10. Christensen, L. P., Kasimatis, A. N., and Jensen, F. L. 1978. Grapevine Nutrition and Fertilization in the San Joaquin Valley. University of California, Agriculture and Natural Resources, Oakland, CA.

11. Clark, M., Horwath, W., Shennan, C., and Scow, K. 1998. Changes in soil chemical properties resulting from organic and low-input farming practices. Agron. J. 90:662-671.

12. Dabire, K. R., Duponnois, R., and Mateille, T. 2001. Indirect effects of the bacterial soil aggregation on the distribution of Pasteuria penetrans, an obligate bacterial parasite of plant-parasitic nematodes. Geoderma 102:139152.

13. Delong, R. L., Lewis, K. J., Simard, S. W., and Gibson, S. 2002. Fluorescent pseudomonad population sizes baited from soils under pure birch, pure Douglas-fir, and mixed forest stands and their antagonism toward Armillaria ostoyae in vitro. Can. J. For. Res. 32:21462159.

14. De Meyer, G., and Hofte, M. 1997. Salicylic acid produced by the rhizobacterium Pseudomonas aeruginosa 7NSK2 induces resistance to leaf infection by Botrytis cinerea in bean. Phytopathology 87:588-593.

15. Dumas, M. T. 1991. Inhibition of Armillaria by bacteria isolated from soils of the Boreal Mixedwood Forest of Ontario. Eur. J. For. Pathol. 22:11-18.

16. Garrett, S. 1957. Effect of a soil microflora selected by carbon disulphide fumigation on survival of Armillaria mellea in woody host tissues. Can. J. Microbiol. 3:135-149. 
17. Gubler, W. D. 1992. Armillaria Root Rot. In: Grape Pest Management, 2nd ed. D. L. Flaherty, L. P. Christensen, W. T. Lanini, J. J. Marois, P. A. Phillips, and L. T. Wilson, eds. Publ. 3343. University of California, Division of Agriculture and Natural Resources, Oakland.

18. Kloepper, J. W., McInroy, J. A., and Bowen, K. L. 1992. Comparative identification by fatty acid analysis of soil, rhizosphere and geocarposphere bacteria of peanut (Arachis hyogaea L.). Plant Soil 139:85-90.

19. Munnecke, D. E., Kolbezen, M. J., and Wilbur, W. D. 1973. Effect of methyl bromide or carbon disulfide on Armillaria and Trichoderma growing on agar medium and relation to survival of Armillaria in soil following fumigation. Phytopathology 63:1352-1357.

20. Munnecke, D. E., Kolbezen, M. J., Wilbur, W.
D., and Ohr, H. D. 1981. Interactions involved in controlling Armillaria mellea. Plant Dis. 65:384-389.

21. Munnecke, D. E., Wilbur, W. D., and Kolbezen, M. J. 1970. Dosage response of Armillaria mellea to methyl bromide. Phytopathology 60:992-993.

22. Ohr, H. D., Munnecke, D. E., and Bricker, J. L. 1973. The interaction of Armillaria mellea and Trichoderma spp. as modified by methyl bromide. Phytopathology 63:965-973.

23. Raabe, R. D. 1966. Testing plants for resistance to oak root fungus. Calif. Agric. 20:12.

24. Raabe, R. D. 1979. Testing grape rootstocks for resistance to the oak root fungus. Calif. Plant Pathol. 46:3-4.

25. Raziq, F., and Fox, R. T. V. 2003. Comparisons between the in vitro and in vivo efficacies of potential fungal antagonists of Armillaria mellea. Biol. Agric. Hortic. 21:263-276.

26. Shaw, C. G., III, and Roth, L. F. 1978. Control of Armillaria root rot in managed coniferous forests. Eur. J. For. Pathol. 8:163-174.

27. Singh, P. 1980. Armillaria root rot: Artificial inoculation and development of the disease in greenhouse. Eur. J. For. Pathol. 10:420-431.

28. Utkhede, R. S. 1984. Antagonism of isolates of Bacillus subtilis to Phytophthora cactorum. Can. J. Bot. 62:1032-1035.

29. Watling, R., Kile, G. A., and Burdsall, H. H. J. 1991. Nomenclature, Taxonomy, and Identification. Pages 1-9 in: Armillaria Root Disease. C. G. Shaw III and G. A. Kile, eds. U.S. Dep. Agric. For. Serv. Agric. Handb. No. 691 , Washington, DC.

30. Winkler, A. J., Cook, J. A., Kliewer, W. M., and Lider, L. A. 1965. General Viticulture. University of California Press, Berkeley. 